\title{
Nurmen fosforilannoituksen satovaste huononlaisen ja tyydyttävän fosforitilan mailla
}

\author{
Sanna Kykkänen ${ }^{1}$, Miika Hartikainen², Maarit Hyrkäs ${ }^{1}$, Perttu Virkajärvi ${ }^{1}$, Minna Toivakka ${ }^{3}$ ja Raimo \\ Kauppila ${ }^{3}$ \\ ${ }^{1}$ Luonnonvarakeskus, Tuotantojärjestelmät, Halolantie 31 A, 71750 Maaninka, \\ etunimi.sukunimi@luke.fi \\ ${ }^{2}$ Luonnonvarakeskus, Tuotantojärjestelmät, Tutkimusasemantie 15, 92400 Ruukki, \\ etunimi.sukunimi@luke.fi \\ ${ }^{3}$ Yara Suomi Oy, Bertel Jungin aukio 9, 02600 Espoo, etunimi.sukunimi@yara.com
}

Nurmen fosforilannoitukselle on tutkimuksissa saatu satovastetta vain harvoin. 2000-luvulla tehdyt fosforilannoitustutkimukset on tehty viljavilla kivennäismailla, joilla mm. vesitalous ja juurten kasvuedellytykset ovat hyvät. Tässä tutkimuksessa haluttiin selvittää fosforin satovastetta raskaalla hiuemaalla ja orgaanisella maalla, joilla maan viljavuusfosforin tila on matalampi kuin aiemmissa kokeissa. Lisäksi tutkittiin nurmentuotantoon kiinteästi liittyvän karjanlannan käyttöä fosforilannoitteena.

Tutkimus toteutettiin vuosina 2015-2017 Luonnonvarakeskuksen Maaningan ja Ruukin toimipaikoilla. Maaningalla koeala perustettiin viljavuusfosforiluokaltaan keskimäärin huononlaiselle (4,6 mg $\left.\mathrm{P}_{\mathrm{AAC}} \mathrm{I}^{-1}\right)$ hiuemaalle ja Ruukissa keskimäärin tyydyttävälle (8,3 $\left.\mathrm{mg} \mathrm{P}_{\mathrm{AAC}} \mathrm{I}^{-1}\right)$ multamaalle. Koekasveina Maaningalla oli timotei-nurminata-seos ja Ruukissa puhdas timoteikasvusto. Perustamisvuonna koekasvina oli suojaviljaksi kylvetty ohra, joka korjattiin kokoviljana. Kokeet suoritettiin osaruutukokeina: pääruutuna lietteenkäyttö (ei lietettä/liete, 30 tn ha ha $^{-1}$ ja osaruutuna mineraalilannoitteena annetut fosforitasot $\left(0,10,20\right.$ ja $\left.40 \mathrm{~kg} \mathrm{P} \mathrm{ha}^{-1} \mathrm{v}^{-1}\right)$. Liete (sis. 10-22 $\mathrm{kg} \mathrm{P} \mathrm{ha}^{-1}$ ) levitettiin sijoittamalla vuonna 2015 kylvön yhteydessä ja nurmivuosina 2. sadolle. Fosforiportaat annettiin pintaan kylvön yhteydessä vuonna 2015 ja 1. sadolle nurmivuosina. Karjanlannan typpi täydennettiin ja typpeä annettiin ympäristökorvausjärjestelmän sallima maksimimäärä (Maaninka 230 $\mathrm{kg} \mathrm{ha}^{-1} \mathrm{v}^{-1}$, Ruukki $190 \mathrm{~kg} \mathrm{ha}^{-1} \mathrm{v}^{-1}$ ). Nurmivuosina korjattiin kolme satoa, joista määritettiin kuivaainesato, rehuarvot ja pääkivennäiset ruuduittain. Maan viljavuusfosforia seurattiin vuosittain.

Vuosina 2015 ja 2016 P-lannoitus ei nostanut satoa P-lannoittamattomaan verrattuna kummallakaan paikkakunnalla (p>0,05). Kokoviljasato oli Maaningalla keskimäärin $3400 \mathrm{~kg} \mathrm{ka} \mathrm{ha}^{-1}$ ja Ruukissa 9300 kg ka ha ${ }^{-1}$, ja nurmisato Maaningalla $10200 \mathrm{~kg} \mathrm{ka} \mathrm{ha}^{-1}$ ja Ruukissa $14100 \mathrm{~kg} \mathrm{ka} \mathrm{ha}^{-1}$. Vuonna 2017 Maaningalla P-lannoitus nosti toisessa korjuussa sadon määrää $200 \mathrm{~kg} \mathrm{ka} \mathrm{ha}^{-1}\left(0 \mathrm{~kg} \mathrm{P} \mathrm{ha}^{-1} \mathrm{vs.} 40 \mathrm{~kg} \mathrm{P}\right.$ $\mathrm{ha}^{-1}, \mathrm{p}=0,01$ ) ja Ruukissa ensimmäisessä korjuussa $30 \mathrm{~kg} \mathrm{P}^{\mathrm{P}}{ }^{-1}$-koejäsenen sato oli $350 \mathrm{~kg} \mathrm{ka} \mathrm{ha}^{-1}$ suurempi kuin 0-ruudun. Ilmiö oli sama liete ja ei lietettä -pääruuduilla.

P-lannoituksella ei ollut vaikutusta kokoviljan P-pitoisuuteen. Vuosina 2016 ja 2017 P-lannoitus nosti 1. sadon P-pitoisuutta sekä Maaningalla että Ruukissa (keskimäärin $2,4 \mathrm{~g} \mathrm{~kg}^{-1} \mathrm{ka} \rightarrow 2,7 \mathrm{~g} \mathrm{~kg}^{-1} \mathrm{ka}$ ). Toisessa sadossa P-lannoitus nosti P-pitoisuutta Ruukissa vuonna 2016 (2,6 g kg $\left.{ }^{-1} \mathrm{ka} \rightarrow 2,8 \mathrm{~g} \mathrm{~kg}^{-1} \mathrm{ka}\right)$, mutta Maaningalla eroa ei ollut (P 3,3 $\mathrm{g} \mathrm{kg}^{-1} \mathrm{ka}$ ). Maaningalla 0-ruudun maan viljavuusfosforipitoisuus laski vuoteen 2017 3,6:een $\mathrm{mg} \mathrm{l}^{-1}$. Ruukissa laskua ei tapahtunut.

Tutkimuksessa saadut tulokset tukevat osin aiempia kokeita. Heikko satovaste osoittaa heinänurmien fosforinoton olevan tehokasta, vaikka fosforia olisikin saatavilla niukasti.

Avainsanat: nurmi, fosfori, viljavuusfosfori 


\section{Johdanto}

Fosfori on välttämätön kasviravinne, jonka saatavuus vaikuttaa nurmikasvuston kehittymiseen ja sadontuottoon. Nurmiheinäkasvien on todettu ottavan tehokkaasti fosforia ja siten aiemmissa tutkimuksissa on harvoin saatu fosforilannoitukselle satovastetta (mm. Valkama ym. 2016, Hartikainen ym. 2017). Valkama ym. 2016 meta-analyysissä fosforilannoituksen todettiin vaikuttavan nurmen sadon tuottoon vasta, kun maan P-tila laskee karkeilla kivennäismailla alle $10 \mathrm{mg} \mathrm{l}^{-1}$ ja orgaanisilla mailla alle $15 \mathrm{mg} \mathrm{l}^{-1}$ maata, edellyttäen että maan $\mathrm{pH}$ on hyvällä tasolla, mutta tällöinkin vaste on epävarma. Fosforin käytön muutokset viimeisten vuosikymmenten aikana, viljelysmaiden fosforitilan lasku, uudet satoisat nurmilajikkeet sekä suppea maalajien määrä aiemmissa fosforilannoituskokeissa osoittivat tarpeen fosforilannoitustutkimukselle. Nurmien fosforilannoituskokeita on tehty 2000-luvulla vain neljä ja ne kaikki on suoritettu viljavilla hietamailla, joilla lannoitusvasteen saaminen on ollut epätodennäköistä. Hiesut ja orgaaniset maat on jätetty tutkimuksen ulkopuolelle. Tähän tutkimukseen valittiin nämä (Hs, Mm) maalajit, koska ne edustavat tyypillisiä nurmiviljelyalueen maalajeja, ovat kasvuedellytyksiltään heikompia ja niillä fosforilannoituksen satovaste olisi odotettu.

Kokeessa tavoitteena oli selvittää heikon fosforitilan mailla: 1) fosforilannoituksen satovaste ja sen vaikutus rehun ruokinnalliseen laatuun, 2) karjanlannan merkitys nurmen fosforilannoitteena ja 3) peltomaan fosforipitoisuuksissa tapahtuvia muutoksia eri fosforilannoitustasoilla. Tässä raportoidaan kokeen perustamisvuoden 2015 ja nurmivuosien 2016-2017 tulokset. Koe jatkuu edelleen vuonna 2018. Koe on toteutettu MMM:n ja Yaran rahoittamassa FOSA-hankkeessa ja Euroopan maaseuturahaston rahoittamassa Ravinnerenki-hankkeessa.

\section{Materiaalit ja menetelmät}

Fosforiporraskokeet suoritettiin osaruutukokeina vuosina 2015-2017 Luonnonvarakeskuksen Maaningan (rm He, 4,6 $\mathrm{mg} \mathrm{P}_{\mathrm{AAC}} \mathrm{l}^{-1}$ ) ja Ruukin (Mm, 8,3 $\mathrm{mg} \mathrm{P}_{\mathrm{AAC}} \mathrm{l}^{-1}$ ) toimipaikoilla. Lietelannoitus (30 tn $\mathrm{ha}^{-1} \mathrm{v}^{-1}$ ) / ei lietelannoitusta muodostivat pääruudun, ja osaruutuina olivat väkilannoitteena annetut fosforilannoitustasot 0, 10, 20 ja $40 \mathrm{~kg} \mathrm{P} \mathrm{ha}^{-1} \mathrm{v}^{-1}$. Kokeet toteutettiin neljänä kerranteena. Koekasveina olivat perustamisvuonna suojaviljaksi kylvetty ohra (kylvömäärä $150 \mathrm{~kg} \mathrm{ha}^{-1}$, Maaningalla Wolmari, Ruukissa Einar) sekä Maaningalla Nuutti-timotei - Valtteri-nurminata -seos (seossuhde 70:30) ja Ruukissa puhdas timotei. Timotein kylvömäärä oli $3000 \mathrm{kpl} \mathrm{m}^{-2}$ ja nurminadan $1250 \mathrm{kpl} \mathrm{m}^{-2}$. Seoskasvuston siemenmäärä laskettiin prosenttiosuuksina puhdaskasvustojen kylvömääristä. Taulukossa 1 on esitetty ennen kokeen perustamista koeruuduittain otettujen maanäytteiden tulosten keskiarvot. Maaningalla koeruutukohtaisten maanäytteiden perusteella koejäsenille lasketut fosforiluokat vaihtelivat välillä huononlainen-välttävä ja Ruukissa vastaavasti luokat olivat välillä välttävä-tyydyttävä. Maaningalla yksittäisten maanäytteiden tulokset painottuivat alempaan luokkaan (huononlainen), kun Ruukissa enemmistö näytteistä kuului vaihteluvälin ylempään luokkaan (tyydyttävä).

Naudan lietelanta (30 tn ha ${ }^{-1} \mathrm{v}^{-1}$ ) levitettiin molemmilla koepaikoilla ruutumittakaavan sijoittavalla lietteen levittimellä ennen kylvöä ja mullattiin äestämällä. Nurmivuosina liete sijoitettiin toiselle sadolle. Fosforiportaat annettiin perustamislannoituksen yhteydessä ja nurmivuosina ensimmäiselle sadolle. Fosforia lukuun ottamatta perustamislannoitus toteutettiin suosituksien mukaan (noin $75 \mathrm{~kg} \mathrm{ha}^{-1}$ liuk. N, $90 \mathrm{~kg} \mathrm{ha}^{-1} \mathrm{~K}$ ). Typpilannoituksessa noudatettiin ympäristökorvausjärjestelmän rajoja. Nurmivuosina ei lietettä -pääruudut saivat Maaningalla $100 \mathrm{~kg} \mathrm{~N} \mathrm{ha}^{-1}$ ensimmäiselle sadolle, $80 \mathrm{~kg} \mathrm{~N} \mathrm{ha}^{-1}$ toiselle sadolle ja $50 \mathrm{~kg} \mathrm{~N} \mathrm{ha}^{-1}$ kolmannelle sadolle. Ruukissa ensimmäinen sato sai $80 \mathrm{~kg} \mathrm{~N} \mathrm{ha}^{-1}$, toinen $70 \mathrm{~kg} \mathrm{~N} \mathrm{ha}^{-1} \mathrm{ja}$ kolmas $40 \mathrm{~kg} \mathrm{~N} \mathrm{ha}^{-1}$. Lietepääruutujen liukoinen typpi pyrittiin täydentämään mineraalilannoitteilla vastaamaan ei lietettä -pääruutua. Ruukissa täydennettiin myös lietteen kaliumia maan heikon reservikaliumtilan vuoksi. Pääruutujen kokoviljavuonna ja nurmivuosina saamat ravinnemäärät (N-PK) ovat esitettynä taulukossa 3. Lietteen käyttömäärät ja koostumus ovat esitettynä taulukossa 2. Maanäytteet otettiin ruuduittain muokkauskerroksesta $(0-20 \mathrm{~cm})$ perustamisvuonna sekä keväällä että syksyllä ja nurmivuosina syksyllä kasvukauden lopussa. Näytteistä analysoitiin perusviljavuus Eurofins Viljavuuspalvelussa (Vuorinen ja Mäkitie 1955).

Perustamisvuonna 2015 suojavilja korjattiin kokoviljana. Nurmesta korjattiin kolme satoa. Korjuiden yhteydessä mitattiin sadon määrä ja otettiin analyysinäytteet. Näytteestä analysoitiin sulavuus (D-arvo, $\mathrm{g} \mathrm{kg}^{-1} \mathrm{ka}$ ) NIR menetelmällä ja P-pitoisuus ( $\mathrm{g} \mathrm{kg}^{-1} \mathrm{ka}$ ) XRF menetelmällä Valio Oy:n Seinäjoen 
aluelaboratoriossa. Tilastoanalyysit tehtiin SAS 9.3 -tilasto-ohjelman MIXED-proseduurilla. Paikkakunnat ja niitot käsiteltiin erikseen. Kasvi- ja maanäytteille käytettiin mallia jossa pääruutu (ei lietettä/liete), osaruutu (P-lannoitustasot) sekä näiden yhdysvaikutus olivat kiinteitä tekijöitä ja kerranne sekä kerranne×pääruutu-yhdysvaikutus satunnaistekijöitä. Parivertailut P-lannoitustasojen välillä tehtiin Tukeyn testillä.

Taulukko 1. Ennen perustamista (kevät 2015) ruuduittain otettujen maanäytteiden keskiarvot.

\begin{tabular}{|c|c|c|}
\hline & Maaninka & Ruukki \\
\hline Maalaji & rm He & $\mathrm{Mm}$ \\
\hline Johtoluku, $10 \mathrm{xmS} \mathrm{cm}^{-1}$ & 0.76 & 2.3 \\
\hline Happamuus, pH & 6.2 & 6.2 \\
\hline Kalsium, mg l' ${ }^{-1}$ & 1703 & 4922 \\
\hline Fosfori, $\mathrm{mg} \mathrm{l}^{-1}$ & 4.6 & 8.3 \\
\hline Kalium, $\mathrm{mg} \mathrm{l}^{-1}$ & 101 & 59 \\
\hline Magnesium, $\mathrm{mg} \mathrm{l}^{-1}$ & 265 & 308 \\
\hline Rikki, mg $\mathrm{l}^{-1}$ & 8.3 & 22.9 \\
\hline Hehkutushäviö, \% & 10.0 & 41.9 \\
\hline
\end{tabular}

Taulukko 2. Kokeilla käytetyn lietelannan käyttömäärä ja koostumus keskimäärin koevuosina 2015-2017.

\begin{tabular}{|c|c|c|}
\hline & Maaninka & Ruukki \\
\hline Liete, käyttömäärä, tn ha ${ }^{-1}$ & 29.9 & 29.6 \\
\hline Lietteen kokonais-N, $\mathrm{kg} \mathrm{tn}^{-1}$ & 2.83 & 3.8 \\
\hline Lietteen liukoinen-N, $\mathrm{kg} \mathrm{t}^{-1}$ & 1.71 & 2.2 \\
\hline Lietteen $\mathrm{P}, \mathrm{kg} \mathrm{tn}^{-1}$ & 0.49 & 0.6 \\
\hline Lietteen $\mathrm{K}$, $\mathrm{kg} \mathrm{t}^{-1}$ & 2.39 & 3.5 \\
\hline Lietteessä kokonais-N kg ha-1 & 84.6 & 93.7 \\
\hline Lietteessä liukoinen-N kg ha ${ }^{-1}$ & 51.1 & 83.1 \\
\hline Lietteessä P kg ha-1 & 14.4 & 19.3 \\
\hline Lietteessä $\mathrm{K} \mathrm{kg} \mathrm{ha}^{-1}$ & 71.5 & 104.0 \\
\hline
\end{tabular}

Taulukko 3. Kokeen pääruutujen lannoituksen kokonaisravinnemäärät (kg ha-1 $\mathrm{v}^{-1}$ ) Maaningalla ja Ruukissa kokoviljavuonna 2015 ja keskimäärin nurmivuosina 2016-2017.

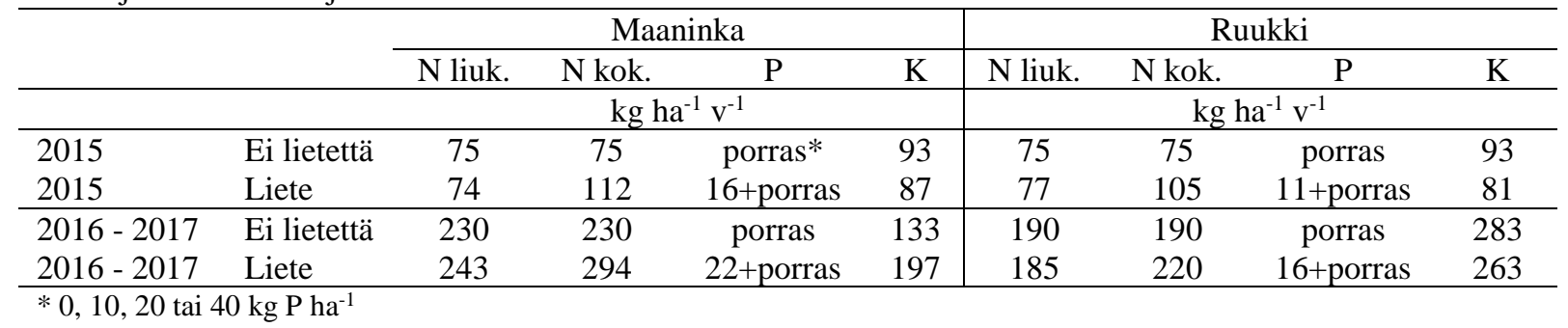

\section{Tulokset}

\section{Sadon määrä ja sulavuus}

Fosforilannoituksen satovaste osoittautui heikoksi myös tässä kokeessa. Perustamisvuonna Maaningan kokoviljasato oli verrattain matala $3440 \mathrm{~kg} \mathrm{ka} \mathrm{ha}^{-1}\left(\mathrm{SEM}=406 \mathrm{~kg} \mathrm{ka} \mathrm{ha}^{-1}\right)$ sadon D-arvon ollessa $591 \mathrm{~g}$ $\mathrm{kg}^{-1} \mathrm{ka}\left(\mathrm{SEM}=11,5 \mathrm{~g} \mathrm{~kg}^{-1} \mathrm{ka}\right.$ ). Koejäsenten välillä ei ollut eroa sadossa tai sulavuudessa ja lannoituksesta johtumaton vaihtelu oli suurta. Ruukissa perustamisvuoden sato oli korkea. Satotaso vaihteli välillä 8300-10 $300 \mathrm{~kg} \mathrm{ka} \mathrm{ha}^{-1}\left(\mathrm{SEM}=474 \mathrm{~kg} \mathrm{ka} \mathrm{ha}^{-1}\right)$. Sadon sulavuus oli lietekoejäsenillä korkeampi kuin pelkän väkilannoituksen saaneilla (586 vs. $566 \mathrm{~g} \mathrm{~kg}^{-1} \mathrm{ka}$; SEM = 8,6 $\mathrm{g} \mathrm{kg}^{-1} \mathrm{ka}$ ). Lietelannoitus nosti tilastollisesti merkitsevästi satoa noin $1000 \mathrm{~kg} \mathrm{ka} \mathrm{ha}^{-1}$ verrattuna ilman lietelannoitusta viljeltyihin koejäseniin. P-portaiden vaikutus Ruukin kokoviljasatoon oli epävarma ja osin epälooginen. Lieteruuduilla P-lannoitus näytti nostavan satotasoa, mutta lannoituksen ero oli tilastollisesti merkitsevä vain matalimman $\left(0 \mathrm{~kg} \mathrm{P} \mathrm{ha}^{-1} \mathrm{v}^{-1}\right)$ ja korkeimman $\left(40 \mathrm{~kg} \mathrm{P} \mathrm{ha}^{-1} \mathrm{v}^{-1}\right) \mathrm{P}$-tason välillä (+ $\left.1100 \mathrm{~kg} \mathrm{ka} \mathrm{ha}^{-1}\right)$, mutta tämäkin ero oli vain suuntaa antava $(\mathrm{p}=0.08)$. Pääruudussa, joka ei saanut lietettä, P-lannoituksella ei ollut vaikutusta satotasoon, mutta vaihtelu oli suurta (korkea SEM). Nurmivuosina kokonaiskuiva-ainesato oli keskimäärin Maaningalla $9400 \mathrm{~kg} \mathrm{ka} \mathrm{ha}^{-1} \mathrm{v}^{-1}$ ja Ruukissa $12500 \mathrm{~kg} \mathrm{ka} \mathrm{ha-1} \mathrm{v}^{-1}$. Paikkakuntien välinen satotaso ero johtunee erilaisesta typen vapautumisesta maasta, mikä on huomattu useissa eri tutkimuksissa aiemmin. Fosforilannoitus nosti vuoden kokonaissatoa ainoastaan vuonna 2017 Ruukissa (+500 kg ka ha-1 $\left.\mathrm{v}^{-1}\right)$. Niittokohtaista satomäärää Plannoitus nosti vuonna 2017 Maaningalla toisessa sadossa (+200 kg ka ha- $\left.\mathrm{k}^{-1}\right)$ ja Ruukissa ensimmäisessä sadossa $\left(+400 \mathrm{~kg} \mathrm{ka} \mathrm{ha}^{-1}\right)$. Yli vuosien tarkastelussa fosforilannoituksen merkitys sadontuotolle oli käytännössä merkityksetön (Taulukko 4 ja 5) ja tilastolliset merkitsevyydet johtuvat pienistä keskivirheistä. Tulokset eroavat odotetusta. Lietelannoitus laski nurmen satotasoa keskimäärin $500 \mathrm{~kg} \mathrm{ka} \mathrm{ha}{ }^{-1}$. Satoero selittyy lietteen levityksen aiheuttamilla mekaanisilla vaurioilla, jotka olivat Maaningalla suuremmat kuin Ruukissa. Osin heikompi satotulos voi johtua heikommasta typen 
hyväksikäyttöasteesta mahdollisen haihtumisen seurauksena. Lieteruutujen hitaampi kehitys näkyy myös hivenen korkeampana D-arvona etenkin toisessa sadossa.

Taulukko 4. Ensimmäisen ja toisen sadon määrä, sulavuus (D-arvo), P-pitoisuus sekä N/P-suhde Maaningalla (M) ja Ruukissa (R) keskimäärin 2016-2017. P-portaat annettu 1. sadolle, liete 2. sadolle. SEM = keskiarvon keskivirhe. Tilastolliset merkitsevyydet: *** $\mathrm{P}<0.001$, ** $\mathrm{P}<0.01, * \mathrm{P}<0.05,0 \mathrm{P}<0.10$.

\begin{tabular}{|c|c|c|c|c|c|c|c|c|c|}
\hline \multirow{2}{*}{$\begin{array}{l}\text { 1. sato } \\
\text { Paikkakunta }\end{array}$} & \multirow[t]{2}{*}{$\begin{array}{c}\text { P-taso } \\
\mathrm{kg} \mathrm{ha}^{-1} \mathrm{v}^{-1}\end{array}$} & \multicolumn{2}{|c|}{$\begin{array}{c}\text { Sato } \\
\text { kg ka ha-1 }\end{array}$} & \multicolumn{2}{|c|}{$\begin{array}{c}\text { D-arvo } \\
\mathrm{g} \mathrm{kg}^{-1} \mathrm{ka}\end{array}$} & \multicolumn{2}{|c|}{$\begin{array}{c}\text { P-pit. } \\
\text { g kg }^{-1} \text { ka }\end{array}$} & \multicolumn{2}{|c|}{ N/P-suhde } \\
\hline & & $\mathrm{M}$ & $\mathrm{R}$ & $\mathrm{M}$ & $\mathrm{R}$ & $\mathrm{M}$ & $\mathrm{R}$ & $\mathrm{M}$ & $\mathrm{R}$ \\
\hline \multirow[t]{4}{*}{ Ei lietettä } & 0 & 4700 & 5200 & 686 & 685 & 2.5 & 2.3 & 8.7 & 10.1 \\
\hline & 10 & 4500 & 5300 & 688 & 693 & 2.5 & 2.5 & 8.8 & 9.5 \\
\hline & 20 & 4500 & 5400 & 689 & 688 & 2.6 & 2.4 & 8.3 & 9.5 \\
\hline & 40 & 4600 & 5400 & 690 & 691 & 2.8 & 2.5 & 8.0 & 9.1 \\
\hline \multirow[t]{4}{*}{ Liete } & 0 & 4700 & 5400 & 693 & 692 & 2.5 & 2.3 & 8.9 & 10.3 \\
\hline & 10 & 4400 & 5400 & 695 & 692 & 2.5 & 2.5 & 9.2 & 9.7 \\
\hline & 20 & 4600 & 5500 & 699 & 694 & 2.6 & 2.5 & 8.6 & 9.8 \\
\hline & 40 & 4600 & 5400 & 690 & 690 & 2.9 & 2.5 & 7.9 & 9.0 \\
\hline SEM & & 123 & 150 & 4.0 & 3.04 & 0.10 & 0.05 & 0.30 & 0.21 \\
\hline \multirow[t]{7}{*}{ Merkitsevyys } & Liete (mp) & $*$ & & $*$ & & $*$ & & $*$ & \\
\hline & P-lann. (sp) & & & & & & $* * *$ & & $* * *$ \\
\hline & Vuosi (v) & $*$ & $*$ & & * & $* * *$ & $*$ & $* * *$ & $* * *$ \\
\hline & $\mathrm{mp} \times \mathrm{sp}$ & & & & & & & & \\
\hline & $\mathrm{v} \times \mathrm{mp}$ & & & $*$ & $*$ & 0 & & $*$ & \\
\hline & $\mathrm{v} \times \mathrm{sp}$ & & & & $*$ & & $*$ & & \\
\hline & $\mathrm{v} \times \mathrm{mp} \times \mathrm{sp}$ & & & & & 0 & & & \\
\hline \multicolumn{10}{|l|}{ 2. sato } \\
\hline \multirow[t]{4}{*}{ Ei lietettä } & 0 & 2900 & 4700 & 696 & 653 & 3.4 & 2.8 & 6.7 & 9.5 \\
\hline & 10 & 2900 & 4700 & 698 & 650 & 3.4 & 2.9 & 6.6 & 8.9 \\
\hline & 20 & 3000 & 4800 & 694 & 657 & 3.5 & 2.9 & 6.3 & 9.2 \\
\hline & 40 & 3100 & 5000 & 694 & 654 & 3.5 & 3.1 & 6.4 & 8.4 \\
\hline Liete, & 0 & 2300 & 4600 & 701 & 658 & 3.6 & 3.2 & 6.2 & 8.4 \\
\hline M 22 kg P ha-1 $\mathrm{v}^{-1}$ & 10 & 2700 & 4500 & 700 & 666 & 3.7 & 3.1 & 6.0 & 8.6 \\
\hline \multirow[t]{2}{*}{ R 16 kg P ha ${ }^{-1} \mathrm{v}^{-1}$} & 20 & 2700 & 4400 & 702 & 656 & 3.7 & 3.1 & 5.7 & 8.1 \\
\hline & 40 & 2400 & 4300 & 701 & 658 & 3.8 & 3.2 & 5.8 & 8.2 \\
\hline SEM & & 56 & 139 & 3.2 & 3.09 & 0.12 & 0.07 & 0.26 & 0.21 \\
\hline \multirow[t]{7}{*}{ Merkitsevyys } & Liete (mp) & $* * *$ & $*$ & $* *$ & $* *$ & $* * *$ & $*$ & & $* * *$ \\
\hline & P-lann. (sp) & $* * *$ & & $*$ & & 0 & $* *$ & $*$ & $*$ \\
\hline & Vuosi (v) & $* *$ & $* * *$ & & $* * *$ & $*$ & $* * *$ & $* *$ & $* * *$ \\
\hline & mp x sp & & $*$ & & $*$ & & * & & $*$ \\
\hline & $\mathrm{v} \times \mathrm{mp}$ & $* * *$ & & $* * *$ & & $* * *$ & $* * *$ & & $* *$ \\
\hline & $\mathrm{v} \times \mathrm{sp}$ & & & & & $*$ & $*$ & $*$ & \\
\hline & v x mp x sp & & & & & & & & \\
\hline
\end{tabular}

\section{Sadon P-pitoisuus ja N/P-suhde}

Perustamisvuoden kokoviljasatojen fosforipitoisuudet olivat taulukkoarvoihin (Luke 2015, 2,5 g kg-1 ka) nähden matalahkot. Maaningalla pitoisuus oli keskimäärin 2,2 $\mathrm{g} \mathrm{kg}^{-1} \mathrm{ka}$ ja Ruukissa 2,0 g kg $\mathrm{ka}^{-1}$. Fosforilannoitus ei vaikuttanut pitoisuuksiin lainkaan, mutta lietelannoitus laski P-pitoisuutta (2,3 vs. 2,1 $\mathrm{g} \mathrm{P} \mathrm{kg}^{-1} \mathrm{ka}$ ). Nurmen P-pitoisuuteen lannoituksella oli selvempi vaikutus (Taulukko 4). P-portaat nostivat nurmisadon P-pitoisuutta erityisesti Ruukissa, jossa P-pitoisuus nousi kaikissa sadoissa Plannoituksen myötä. Selvintä nousu oli pääruudussa joka ei saanut lietettä. Tällöin P-pitoisuus nousi +

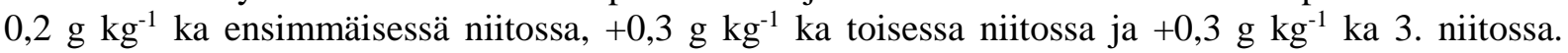
Maaningalla P-lannoitus nosti sadon P-pitoisuutta vain yksittäisinä vuosina ja yksittäisissä sadoissa. Nurmisadon N/P-suhde vaihteli Maaningalla välillä 5,6-9,1 ja Ruukissa välillä 8,3-1,0, mutta fosforin puutetta ei havaittu, eikä siten kriittistä P-pitoisuutta voitu määrittää tarkasti. 


\section{P-tase ja maan P-luku}

Ilman lietteen käyttöä nurmivuosien keskimääräiset kokonaisfosforitaseet olivat negatiivisia lukuun ottamatta korkeinta P-lannoitusporrasta $\left(40 \mathrm{~kg} \mathrm{P} \mathrm{ha}^{-1} \mathrm{v}^{-1}\right)$, jolloin P-tase oli Maaningalla keskimäärin 9 kg P ha ${ }^{-1} \mathrm{v}^{-1}$ ja Ruukissa $2 \mathrm{~kg} \mathrm{P} \mathrm{ha}{ }^{-1} \mathrm{v}^{-1}$ (Taulukko 5). Kolmella alemmalla P-portaalla ei lietettä pääruudulla taseet vaihtelivat Maaningalla keskimäärin $-10--29 \mathrm{~kg} \mathrm{P} \mathrm{ha}^{-1} \mathrm{v}^{-1}$ ja Ruukissa $-15--33 \mathrm{~kg}$ $\mathrm{P} h \mathrm{ha}^{-1} \mathrm{v}^{-1}$. Lietteen käyttö nosti taseen lähemmäksi nollaa tai positiiviseksi. Ruukissa tase pysyi keskimäärin negatiivisena tai nollana myös lietettä saaneilla ruuduilla kolmella matalimmalla Pportaalla.

Väkilannoitefosfori ( 0 vs. $40 \mathrm{~kg} \mathrm{P} \mathrm{ha}^{-1} \mathrm{v}^{-1}$ ) nosti muokkauskerroksen P-pitoisuutta Maaningalla 3.8:sta $\mathrm{mg} \mathrm{l}^{-1}$ 5.2:een $\mathrm{mg} \mathrm{l}^{-1}$ ja Ruukissa 7,8:sta $\mathrm{mg} \mathrm{l}^{-1}$ 10.3:aan $\mathrm{mg} \mathrm{l}^{-1}$ (Taulukko 6). Viimeisenä koevuonna 2017 lietettä saaneiden ja ei -lietettä saaneiden ruutujen maan P-luvut eivät eronneet toisistaan. Koejakson aikana täysin ilman fosforilannoitusta olleen ruudun maan P-luku aleni Maaningalla 1,8 mg $\mathrm{l}^{-1}$ ja Ruukissa 0,4 $\mathrm{mg} \mathrm{l}^{-1}$ ollen kokeen lopussa Maaningalla $3.6 \mathrm{mg} \mathrm{l}^{-1}$ ja Ruukissa $7.5 \mathrm{mg} \mathrm{l}^{-1}$.

Taulukko 5. Kesän kokonaissato (tn ka ha-1) ja vuotuinen P-tase $\left(\mathrm{kg} \mathrm{ha}^{-1} \mathrm{v}^{-1}\right)$ 2016-2017. SEM = keskiarvon keskivirhe. Tilastolliset merkitsevyydet: *** $\mathrm{P}<0.001$, ** $\mathrm{P}<0.01, * \mathrm{P}<0.05,0 \mathrm{P}<0.10$.

\begin{tabular}{|c|c|c|c|c|c|c|c|c|c|c|c|c|c|c|c|c|c|}
\hline & \multirow{3}{*}{$\begin{array}{c}\text { Paikkakunt } \\
\text { a }\end{array}$} & \multicolumn{4}{|c|}{$\begin{array}{c}\text { Ei lietettä } \\
\text { P-taso, kg } \mathrm{P} \mathrm{ha}^{-1} \mathrm{v}^{-1}\end{array}$} & \multicolumn{4}{|c|}{$\begin{array}{l}\text { Liete }\left(15 \mathrm{~kg} \mathrm{P} \mathrm{ha-1} \mathrm{v}^{-1}\right) \\
\text { P-taso, } \mathrm{kg} \mathrm{P} \mathrm{ha}^{-1} \mathrm{v}^{-1}\end{array}$} & \multirow{3}{*}{$\begin{array}{l}\mathrm{SE} \\
\mathrm{M}\end{array}$} & \multirow{3}{*}{\multicolumn{3}{|c|}{$\begin{array}{l}\text { Merkitsevyys } \\
\mathrm{mp} \text { sp v }\end{array}$}} & \multirow{3}{*}{$\begin{array}{c}\mathrm{m} \\
\mathrm{p} x \\
\mathrm{sp}\end{array}$} & \multirow{3}{*}{$\begin{array}{l}\mathrm{Vx} \\
\mathrm{mp}\end{array}$} & \multirow{2}{*}{$\begin{array}{l}V \\
X \\
s \\
p\end{array}$} & \multirow{3}{*}{$\begin{array}{c}\mathrm{vx} \\
\mathrm{m} \\
\mathrm{px} \\
\mathrm{sp}\end{array}$} \\
\hline & & 0 & 10 & 20 & 40 & 0 & 10 & 20 & 40 & & & & & & & & \\
\hline & & & & & & & & & & & & & & & & $\mathrm{p}$ & \\
\hline \multirow[t]{2}{*}{ Sato } & Maaninka & 9.7 & 9.6 & 9.6 & 9.7 & 9.2 & 8.9 & 9.0 & 9.2 & 0.12 & $\begin{array}{c}* * \\
*\end{array}$ & $\begin{array}{c}* * \\
*\end{array}$ & $* *$ & & $\begin{array}{c}* * \\
*\end{array}$ & 0 & \\
\hline & Ruukki & $\begin{array}{c}12 . \\
4 \\
\end{array}$ & $\begin{array}{c}12 . \\
4\end{array}$ & $\begin{array}{c}12 . \\
7 \\
\end{array}$ & $\begin{array}{c}13 . \\
0\end{array}$ & $\begin{array}{c}12 . \\
5 \\
\end{array}$ & $\begin{array}{c}12 . \\
5\end{array}$ & $\begin{array}{c}12 . \\
5 \\
\end{array}$ & $\begin{array}{c}12 . \\
3 \\
\end{array}$ & 0.18 & & & $\begin{array}{c}* * \\
* \\
\end{array}$ & $*$ & $* *$ & & \\
\hline \multirow[t]{2}{*}{$\begin{array}{l}\mathrm{P}- \\
\text { tase }\end{array}$} & Maaninka & -29 & -19 & -10 & 9 & -6 & 4 & 13 & 31 & 0.9 & $*$ & $\begin{array}{c}* * \\
*\end{array}$ & $\begin{array}{c}* * \\
*\end{array}$ & & $*$ & $*$ & \\
\hline & Ruukki & -33 & -25 & -15 & 2 & -20 & -10 & 0 & 19 & 0.8 & $\begin{array}{c}* * \\
*\end{array}$ & $\begin{array}{c}* * \\
*\end{array}$ & $\begin{array}{c}* * \\
*\end{array}$ & $* *$ & $\begin{array}{c}* * \\
*\end{array}$ & $*$ & $*$ \\
\hline
\end{tabular}

Taulukko 6. P-lannoituksen vaikutus maan P tilaan (mg $\mathrm{P}_{\mathrm{AAC}} \mathrm{l}^{-1}$ ) ennen kokeen alkua 2015 ja syksyllä 2017. SEM = keskiarvon keskivirhe. Tilastolliset merkitsevyydet: *** $\mathrm{P}<0.001,{ }^{* *} \mathrm{P}<0.01, * \mathrm{P}<0.05,0 \mathrm{P}<0.10$. Tilastomallissa on laskettu kaikki yhdysvaikutukset, mutta niiden merkitsevyyksiä ei esitetä tässä.

\begin{tabular}{|c|c|c|c|c|c|c|c|c|c|c|c|c|c|}
\hline \multirow[b]{2}{*}{ Paikkakunta } & & \multicolumn{4}{|c|}{$\begin{array}{c}\text { Ei lietettä } \\
\text { P-taso, kg } \mathrm{P} \mathrm{ha}^{-1} \mathrm{v}^{-1}\end{array}$} & \multicolumn{4}{|c|}{$\begin{array}{l}\text { Liete }\left(15 \mathrm{~kg} \mathrm{P} \mathrm{ha-1} \mathrm{v}^{-1}\right) \\
\text { P-taso, kg P ha }{ }^{-1} \mathrm{v}^{-1}\end{array}$} & \multirow[t]{2}{*}{ SEM } & \multicolumn{3}{|c|}{ P-arvo } \\
\hline & & 0 & 10 & 20 & 40 & 0 & 10 & 20 & 40 & & $\mathrm{mp}$ & $\mathrm{sp}$ & $\mathrm{mp} \times \mathrm{sp}$ \\
\hline Maaninka & 2015 & 5.5 & 4.6 & 4.7 & 4.2 & 4.5 & 4.5 & 4.8 & 4.2 & 0.46 & 0 & & \\
\hline Maaninka & 2017 & 3.6 & 4.1 & 4.4 & 4.9 & 3.9 & 4.5 & 5.1 & 5.6 & 0.42 & & $* * *$ & \\
\hline Ruukki & 2015 & 8.0 & 7.7 & 8.4 & 8.8 & 7.9 & 8.3 & 8.9 & 8.7 & 0.59 & 0 & & \\
\hline Ruukki & 2017 & 7.5 & 7.9 & 9.1 & 9.7 & 8.2 & 9.4 & 9.7 & 10.9 & 0.71 & & $* *$ & \\
\hline
\end{tabular}

\section{Tulosten tarkastelu}

\section{Sadon määrä}

Tässä kokeessa fosforilannoituksella oli vaikutusta sadon määrään vain yksittäisinä vuosina, yksittäisissä niitoissa. Tulos oli osin yllättävä ja osoitti nurmikasvien tehokkaan fosforin oton myös suhteellisen matalassa maan P-luokassa. Valkama ym. (2009, 2016) meta-analyysin perusteella fosforilannoituksen satovaste olisi sekä viljalla että nurmilla odotettu, kun maan P-tila laskee karkeilla kivennäismailla alle $10 \mathrm{mg} \mathrm{l}^{-1}$ maata tai orgaanisilla mailla alle $15 \mathrm{mg} \mathrm{l}^{-1}$ maata, kun maan rakenne ja pH ovat hyviä. Tämän perusteella lannoitusvastetta odotettiin. Fosforilannoituksen merkitys korostuu kylmissä ja kosteissa olosuhteissa. Kasvukausi 2017 oli poikkeuksellisen kylmä ja sateinen, mutta fosforilannoituksen merkitys jäi silti olemattomaksi.

\section{N/P-suhde ja kriittinen P-pitoisuus}

Kokoviljan ja nurmen fosforipitoisuus riippuu mm. maan P-luvusta ja lannoituksesta sekä kasvuston kehitysasteesta ja lehti/korsi -suhteesta. P-pitoisuus vaihtelee paljon erityisesti ympäristöolosuhteiden 
(kosteus, lämpötila) mukaan ja huonoissa oloissa (märkyys, kuivuus, kylmyys) lannoitus vaikuttaa vähemmän nurmen P-pitoisuuteen kuin olosuhteet (Mustonen 2013, Ylivainio ym. 2017). Fosforia on yleensä enemmän lehdissä kuin korsissa ja siten korrellisen kasvuston P-pitoisuus voi olla huomattavasti lehtevää kasvustoa matalampi. Tähän viittaavat myös tämän kokeen tulokset, joissa enemmän kortta sisältävän 1. sadon P-pitoisuus oli huomattavasti matalampi, kuin vähäkortisemman toisen ja kolmannen sadon (nurminata ei muodosta kortta toiseen tai kolmanteen satoon). Koska Ruukissa kasvusto oli puhdasta timoteitä (muodostaa kortta myös jälkisatoihin), siellä myös toisen sadon P-pitoisuus oli suhteellisen matala. Näiden seikkojen vuoksi pelkkä kasvuston P-pitoisuus ilman sadon määrää on epätarkka nurmen fosforilannoitustarpeen indikaattori.

Nurmen P-pitoisuuden on todettu olevan vahvasti yhteydessä nurmen typpipitoisuuteen - aktiiviset solukot tarvitsevat sekä typpeä että fosforia enemmän kuin rakenteelliset solukot. Siksi kasvuston N/P -suhde kuvaa teoriassa paremmin kasvuston fosforin riittävyyttä kuin kasvin P-pitoisuus (Bélanger ja Ziadi 2008, Bélanger ym. 2017). Kuvassa 1a on tarkasteltu koeaineiston N/P-suhteen ja sadon yhteyttä. Lisäksi kuvassa ovat P-tarpeen indikaattoreina Greenwoodin ym. (2008) ja Belangerin ym. (2017) kriittisen N/P-suhteen funktiot. Fosforilannoituksen tulisi lisätä satoa, kun havainto asettuu käyrien yläpuolelle. Aiemmin on esitetty, ettei nurmi kärsi Suomessa fosforin puutteesta, kun N/P suhde on alle 8 (Saarela 2005) tai alle 10 (Virkajärvi ym. 2015). Tässä kokeessa N/P-suhde oli suurimmillaan 11.1 (Ruukki 2016, 1. sato), mutta satovastetta ei havaittu. Toisaalta Maaningalla havaittiin satovaste, vaikka N/P-suhde oli vain 6.6. Siten N/P-suhde näyttää Suomen oloissa olevan huono P-tarpeen indikaattori. Nurmen fosforitarvetta voidaan arvioida myös laskemalla kriittinen P- pitoisuus biomassan funktiona ( $\mathrm{P}_{\mathrm{c}}$; Belangér ja Ziadi 2008, Kuva 1b). Mikäli kasvuston $\mathrm{P}$-pitoisuus on alempi kuin $\mathrm{P}_{\mathrm{c}}$, rajoittaa $\mathrm{P}$ kasvua. Tässä aineistossa P-pitoisuuden ja nurmen biomassan yhteys on huomattavasti vahvempi kuin N/P suhteen ja biomassan. Kokeen havainnot asettuvat melko hyvin Belanger ja Ziadin (2008) käyrälle riippumatta niitosta. Jos havainnot olisivat asettuneet huomattavasti käyrän alapuolelle, fosforilannoituksella olisi voitu odottaa olevan satovaste. Sekä N/P että $\mathrm{P}_{\mathrm{c}}$ sadon määrän funktiona on luotettava vain, kun muut kasvutekijät kuin fosfori eivät rajoita kasvua.
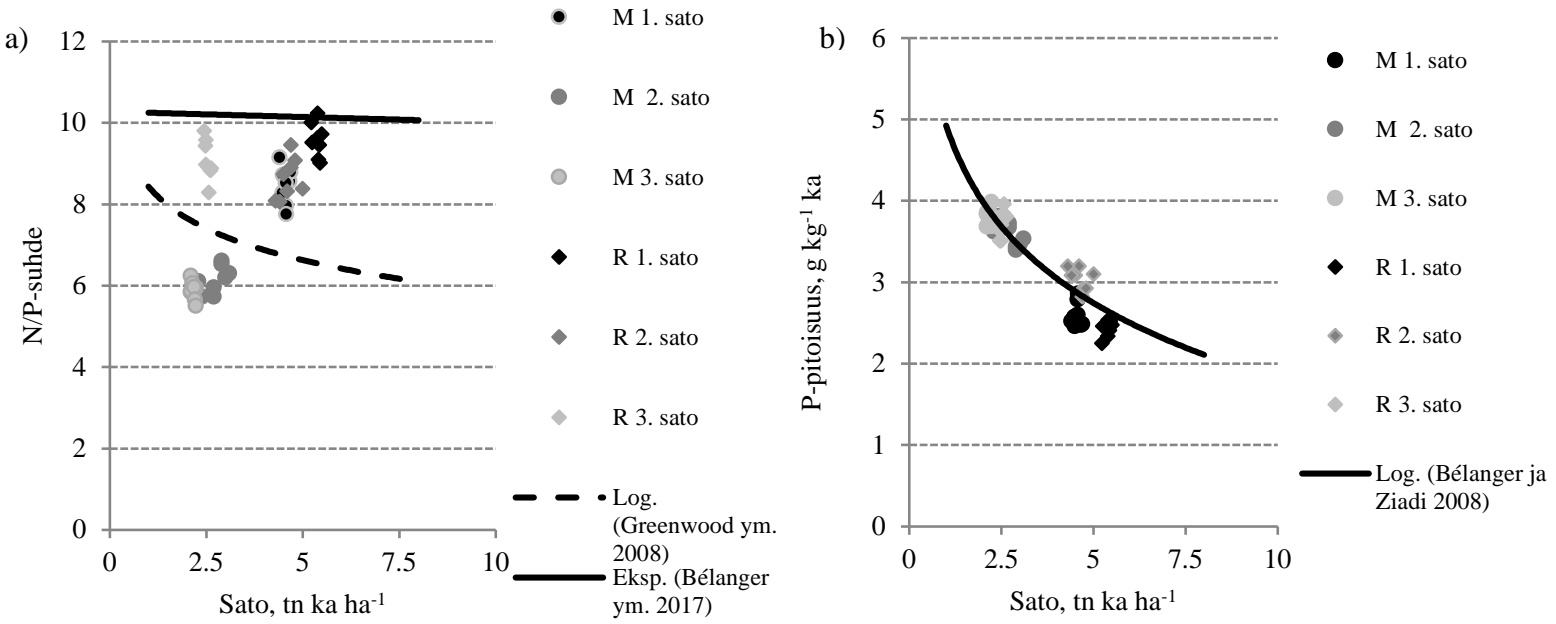

Kuva 1. a) N/P-suhteen ja b) P-pitoisuuden yhteys sadon määrään. P-tarpeen indikaattoreina ovat Greenwoodin ym. (2008) ja Belangerin ym. (2017) kriittisen N/P-suhteen funktiot sekä Belangér ja Ziadin (2008) kriittisen Ppitoisuuden funktio. $\mathrm{M}=$ Maaninka, $\mathrm{R}=$ Ruukki

\section{P-tase ja maan P-luku}

Nurmivuosien P-taseet olivat yleisesti negatiivisia lukuun ottamatta korkeinta P-lannoitustasoa, kun lietettä ei käytetty. Lietteen käyttö nosti P-taseita lähemmäksi nollaa tai positiivisiksi, mutta ne jäivät kuitenkin hyvin maltillisiksi. Nurmien tehokas fosforinotto on havaittu monissa viimeaikaisissa kokeissa (Virkajärvi ym. 2016, Hartikainen ym. 2017). Lieteruutujen korkeampi tase johtui paitsi korkeammasta kokonaisfosforilannoituksesta, myös matalammasta satotasosta erityisesti Maaningalla. Tyydyttävässä viljavuusluokassa fosforilannoituksen poisjättämisellä ei ole havaittu olevan vaikutusta satotasoon (mm. Valkama ym. 2016, Hartikainen ym. 2017). Jos maan P-tila laskee tyydyttyväänvälttävään luokkaan, P-lannoituksella tulisi pysäyttää maan P-luvun lasku, jotta fosfori ei ala rajoittaa nurmen kasvua. Koepaikkojen maan fosforitila oli kokeen lopussa Maaningalla edelleen luokassa 
huononlainen kaikilla lannoituskäsittelyillä. Huononlaisessa luokassa lannoitussuositus on satotasokorjauksella $38 \mathrm{~kg} \mathrm{P} \mathrm{ha}^{-1}$. Maaningalla maan P-luku nousi, kun kokonais-P-lannoitus oli tasolla $40 \mathrm{~kg} \mathrm{P} \mathrm{ha}^{-1} \mathrm{v}^{-1}$. Ruukissa P-luku oli kokeen lopussa välttävässä - tyydyttävässä luokassa. Kymmenen kg:n kokonaisfosforilannoitus ( $\left.\mathrm{kg} \mathrm{ha}^{-1}\right)$ riitti Ruukissa ylläpitämään maan P-lukua ja jopa nostamaan sitä hiukan. Fosforitase korreloi maan P-luvun muutoksen kanssa vaikka aineistoa oli vain kolmen vuoden ajalta. Kokeen tulosten perustella huononlaisen-tyydyttävän viljavuusluokan suosituslannoituksella maan P-tila pystytään pitämään vakaana ja alimmissa luokissa tilaa nostamaan. Koepaikkojen maalajit erosivat kuitenkin kyvyssään ylläpitää maan viljavuusfosforipitoisuutta. Satotasokorjauksella välttävässä luokassa P-lannoitussuositus on $30 \mathrm{~kg} \mathrm{P} \mathrm{ha}^{-1}$ ja tyydyttävässä luokassa $20 \mathrm{~kg} \mathrm{P} \mathrm{ha}{ }^{-1}$. Maan P-tila on laskenut 0-fosforilannoituksella Maaningalla 3.6:een $\mathrm{mg} \mathrm{l}^{-1}$ ja Ruukissa 7.5:een $\mathrm{mg} \mathrm{l}^{-1}$. On odotettavaa, että kokeen kolmantena nurmivuonna 2018 fosforilannoitukselle saadaan satovaste.

\section{Johtopäätökset}

Fosforilannoitus ei nostanut kokoviljan eikä nurmen satoa huononlaisen ja tyydyttävän fosforitilan mailla ensimmäisten kolmen vuoden aikana. Lietteen sisältämä fosfori riittää yhdessä maan P-varojen kanssa useassa tilanteessa täyttämään nurmen fosforintarpeen mikä johtuu nurmen hyvästä kyvystä ottaa fosforia maasta. Laajemmin tarkasteltuna korkea satotaso johtaa negatiiviseen P-taseeseen ja edelleen maan P-luokan alentumiseen. Heikon P-tilan mailla lasku voi aiheuttaa ongelmia pitkällä aikavälillä, etenkin jos viljelykierrossa on nurmea vaateliaampia viljelykasveja. N/P -suhde osoittautui olevan Suomen olosuhteissa huono P-tarpeen kuvaaja. Sen sijaan nurmen $\mathrm{P}_{\mathrm{c}}$, joka lasketaan nurmen massan funktiona, näytti olevan lupaava nurmen P-tarpeen indikaattori. Tämän tutkimuksen perusteella huononlainen - tyydyttävän viljavuusluokan maalla nykyiset lannoitusrajat riittävät pitämään maan Pluvun vakaana tai nostamaan sitä alhaisissa viljavuusluokissa. Maalajeissa saattaa kuitenkin olla suuria eroja maan P-luvun ylläpitämisessä.

\section{Kirjallisuus}

Bélanger, G. \& Ziadi, N. 2008. Phosphorus and nitrogen relationships during spring growth of an aging timothy sward. Agronomy Journal 100: 1757-1762.

Bélanger, G., Ziadi, N., Lajeunesse, J., Jouany, C., Virkajarvi, P., Sinaj, S. \& Nyiraneza, J. 2017.

Phosphorus-nitrogen relationships of forage grasses in response to mineral phosphorus fertilization. Field Crops Research 204: 31-41.

Greenwood, D.J., Karpinets, T.V., Zhang, K., Bosh-Serra, A., Boldrini, A. \& Karawulova,L. 2008. A unifying concept for the dependence of whole-crop N:P ratio on biomass: theory and experiment. Annals of Botany 102: 967-977.

Hartikainen, M., Kykkänen, S., Hyrkäs, M., Virkajärvi, P., Suomela, R \& Luoma, S. 2017. Nurmen Pkertalannoitus (Yara N1). Teoksessa: Kanninen, J. (Toim.). Lannoitus- ja kasvinsuojelukokeiden tuloksia 20142016. Kuopion kaupungin painatuskeskus. $59 \mathrm{~s}$.

Luke 2015. Rehutaulukot ja ruokintasuositukset. Luonnonvarakeskus, Helsinki 2015.

Mustonen, A. 2013. Seitsemän lihavaa vuotta - vieläkö nurmen fosforilannoituksesta voidaan tinkiä? ProGradututkielma. Helsingin yliopisto.

Pakarinen, K, Virkajärvi, P., Pietikäinen, L. \& Isolahti, M. 2007. Nurmen P-kertalannoitus (Yara N1). Teoksessa: Issakainen, P. (Toim.). Lannoitus- ja kasvinsuojelukokeiden tuloksia 2006. Kuopion kaupungin painatuskeskus. $87 \mathrm{~s}$.

Saarela, I. 2005. Nurmen fosforitalous. Nurmitieto 2.2.2. Suomen Nurmiyhdistyksen ja MTT:n julkaisusarja. Julkaisupäivä: 17.3.2005. http://www.nurmiyhdistys.fi/Nurmitieto/NT_2-2-2.pdf

Valkama E., Uusitalo R., Ylivainio K., Virkajärvi P. \& Turtola E. 2009. Phosphorus fertilization: a metaanalysis of 80 years of research in Finland. Agriculture, Ecosystems and Environment 130: 75-85.

Valkama, E., Virkajärvi, P., Uusitalo, R., Ylivainio, K. \& Turtola, E. 2016. Meta-analysis of grass ley response to phosphorus fertilization in Finland. Grass and Forage Science 71: 36-53.

Virkajärvi, P., Kykkänen, S. \& Hyrkäs, M. 2015. Nurmikasvien fosforin puutteen arviointi kasvin ravinnesuhteiden avulla - kasvidiagnostiikka. Teoksessa: Ruokojärvi, A. (Toim.). Ravinnehävikit euroiksi. RAE-hankkeen (2011-2015) loppuraportti. Savonia-ammattikorkeakoulun julkaisusarja D4/2/2015. 149 s. Virkajärvi, P., Hyrkäs, M., Räty, M., Pakarinen, T., Pyykkönen, V. \& Luostarinen, S. 2016. Biokaasuteknologiaa maatiloilla II. Biokaasulaitoksen käsittelyjäännöksen hyödyntäminen lannoitteena. Luonnonvara- ja biotalouden tutkimus 37/2016, 115 s. http://urn.fi/URN:ISBN:978-952-326-266-9 
Vuorinen, J. \& Mäkitie, O. 1955. The method of soil testing in use in Finland. Agrogeological Publications 63: 1-44.

Ylivainio, K., Jauhiainen, L., Uusitalo, R. \& Turtola, E. 2017. Waterlogging severely retards P use efficiency of spring barley (Hordeum vulgare). Journal of Agronomy and Crop Science 204: 74-85 